\title{
Analisis Hukum Pengujian Peraturan Desa
}

\author{
Legal Analysis of Village Regulation Testing
}

\author{
Asri \\ Universitas Halu Oleo \\ E-mail: ariasri425@gmail.com \\ Guasman Tatawu \\ Pascarjana Universitas Halu Oleo \\ E-mail: gtatawu@gmail.com \\ Kamaruddin Jafar \\ Pascarjana Universitas Halu Oleo \\ E-mail: kamaruddinjafar88@gmail.com
}

\begin{abstract}
The purpose of this research is to find out and analyze the testing of the cancellation of village regulations, and to find out and analyze the testing of regulations in the legal system in Indonesia. This research is a normative research which is based on reviewing the laws and regulations relating to issues, especially laws and regulations relating to village regulations. The result of the research is that the authority of the Supreme Court to examine the statutory provisions under the law constitutes the constitutional authority of the provisions of article 24A paragraph (1) of the 1945 Constitution. And furthermore, based on the provisions of article 20 paragraph (1) of the Act. No. 48/2009 Concerning Judicial Power, it has been determined that the Supreme Court is the highest state court of the judiciary within the four judicial spheres. Then in article (2) paragraph of the Judicial Power Law the enumerative authority of the Supreme Court has also been determined namely: a) adjudicating at the level of appeal against decisions made at the final level by courts in all judicial environments under the Supreme Court, except for the law determine others, b) examine the statutory regulations under the law against the law, c) other authorities granted by law.
\end{abstract}

Keyword: Authority, Testing; Village Regulations

Abstrak: Tujuan dalam penelitian ini adalah untuk mengetahui dan menganalisis pengujian pembatalan peraturan desa, dan untuk mengetahui dan menganalisis pengujian peraturan dalam sistem hukum di Indonesia. Penelitian ini merupakan penelitian normatif yang didasarkan dengan cara mengkaji peraturan perundangundangan yang berhubungan dengan permasalahan khususnya peraturan perundangundangan yang berkaitan dengan peraturan desa. Hasil penelitian bahwa kewenangan Mahkamah Agung untuk menguji peraturan perundang-undangan di bawah undangundang merupakan kewenangan konstitusional dari ketentuan Pasal 24A ayat (1) UUD 1945. Dan selanjutnya, berdasarkan ketentuan Pasal 20 ayat (1) Undang-Undang Republik 
Indonesia Nomor 48/2009 Tentang Kekuasaan Kehakiman telah ditentukan bahwa Mahkamah Agung merupakan pengadilan negara tertinggi dari badan peradilan yang berada di dalam keempat lingkungan peradilan. Kemudian dalam Pasal (2) ayat UU Kekuasaan Kehakiman telah ditentukan juga kewenangan Mahkamah Agung secara enumeratifyakni: a) mengadili pada tingkat kasasi terhadap putusan yang diberikan pada tingkat terakhir oleh pengadilan di semua lingkungan peradilan yang berada di bawah Mahkamah Agung, kecuali undang-undang menentukan lain, b) menguji peraturan perundang-undangan di bawah undang-undang terhadap undang-undang, c) kewenangan lainnya yang diberikan undang-undang.

Kata kunci: Kewenangan, Pengujian; Peraturan Desa

\section{PENDAHULUAN}

Dalam peraturan pemerintah, yang dimaksud dengan Desa adalah Desa dan Desa adat atau yang disebut dengan nama lain selanjutnya disebut Desa, adalah kesatuan masyarakat hukum yang memiliki batas wilayah yang berwenang untuk mengatur dan mengurus urusan pemerintahan, kepentingan masyarakat setempat berdasarkan prakarsa masyarakat, hak asal usul, dan atau hak tradisional yang diakui dan dihormati dalam sistem pemerintahan Negara Kesatuan Republik Indonesia. ${ }^{1}$ Melihat pemerintahan Desa yang berdasarkan prakarsa masyarakat, hak asal usul, dan atau hak tradisional tentunya desa di Indonesia memiliki cukup ragam dan jenis Desa yang berbeda-beda.

Pemberian Otonomi Desa berdasarkan Undang-Undang Desa dimana Desa memiliki kewenangan dalam mengatur dan mengurus kepentingan masyarakat setempat menurut prakarsa sendiri berdasarkan aspirasi masyarakat Desa, merupakan kesadaran pemerintah atas pentingnya peranan pemerintah Desa yang sangat dekat dengan masyarakat dalam mencapai kesejahteraan dan keadilan sebagai mana yang dituangkan dalam UUD 1945 alinea terakhir. Untuk mencapai keadilan dan kesejahteraan, maka pemerintah desa membentuk peraturan Desa sebagai dasar pengambilan kebijakan atas berjalannya pemerintahan yaitu peraturan Desa yang dibuat dan di sepakati oleh Kepala desa bersama Badan Permusyawaratan Desa.

Namun berdasarkan Pasal 87 Peraturan Pemerintah Nomor 43 Tahun 20142014 tentang Peraturan Pelaksanaan Undang-Undang Republik Indonesia Nomor 6 Tahun 2014 Tentang Desa, (selanjutnya disingkat PP 43/2014) sebagai peraturan pelaksana UndangUndang Republik Indonesia Nomor 6 Tahun 2014 tentang Desa (selanjutnya disingkat UU 6/2014) bahwa peraturan desa yang dibentuk dan disepakati Kepala Desa bersama Badan

1 Pasal 1 Peraturan Pemerintah Nomor 43 Tahun 2014 tentang Peraturan Pelaksanaan Undang-Undang Republik Indonesia Nomor 6 Tahun 2014 Tentang Desa 
Permusyawaratan Desa bisa saja di batalkan oleh Bupati atau Walikota bila mana peraturan Desa tersebut bertentangan dengan kepentingan umum maupun dengan peraturan yang lebih tinggi. Sementara, sebagai bentuk peraturan ditingkat desa, dimana unit pemerintahan desa sudah seharusnya dibedakan dari unit pemerintahan daerah pada umumnya. ${ }^{2}$ Adapun yang di maksud adalah sebagai mana yang di jelaskan di bawah ini.

Berdasarkan UU 6/2014 tentang Desa dengan peraturan pelaksananya, PP 43/2014 Tentang Desa, menggambarkan tidak seriusnya pemerintah terkait pemberian otonomi terhadap Desa sebagai otonomi yang memiliki keunikan pemerintahan yaitu hak tradisional yang pada akhirnya akan mempengaruhi pembentukan peraturan desa dimana pemerintah desa itu merupakan pemerintahan pertama yang ada sebelum Indonesia merdeka namun disisi lain peraturannya dapat dibatalkan oleh Bupati/Walikota. Sementara dalam Undang-undang Nomor 12 Tahun 2011 tentang Pedoman Pembentukan Peraturan Perundang-undangan Pasal 9 tidak mengenal pengujian peraturan perundang-undangan di bawah undang-undang yang dilakukan oleh Bupati/Walikota (Eksekutif). Olehnya itu dapat diartikan bahwa kedudukan Desa berada di bawah kekuasaan pemerintah.

Apabila dilihat dari penjelasan di atas, pemerintahan Desa sebagai pemerintahan pertama sebelum dan sesudah Indonesia merdeka serta memiliki hukum yang unik yaitu berdasarkan prakarsa masyarakat serta hak asal usul dan serta hak tradisional sebagai suatu keistimewaan. Maka sudah sepantasnya pemerintah desa memperoleh kepastian hukum atas pembatalan peraturan Desa yang dilakukan oleh Bupati/Walikota.

Dari ketentuan di atas, dapat ditegaskan bahwa apabila dicermati lebih lanjut kewenangan Desa dalam hal ini sangat besar, karena Desa memiliki otonomi khusus, yaitu kewenangan untuk mengatur dan mengurus rumah tangganya sendiri. Bila mana peraturan desa dibatalkan oleh Bupati atau Walikota yang menjadi pertanyaan adalah apakah pembatalan oleh Bupati atau Walikota itu dapat dilakukan pengujian berdasarkan sistem hukum di Indonesia? Dalam hal ini peraturan desa yang bertentangan dengan peraturan daerah, dimana suatu peraturan perundang-undangan dapat dilakukan evaluasi serta diajukan ke Mahkamah Agung ataupun Mahkamah Konstitusi untuk dilakukan pengujian secara materiil apabila bertentangan dengan Undang-Undang yang lebih tinggi. Ketentuan ini sebagaimana yang dijelaskan berdasarkan Undang-Undang Republik Indonesia Nomor 12 Tahun 2011 tentang Pembentukan Peraturan Perundang-undangan bahwa Peraturan perundang-undangan yang

2 Jimly Asshidqie, Pengantar Ilmu Hukum Tata Negara, Jilid I, Jakarta: Sekretariat Jendral dan Kepanitraan MK RI, 2006, hlm. 222 
bisa dilakukan pengujian adalah dari tingkat Undang-Undang terhadap Undang-Undang Dasar hingga tingkatan yang paling rendah, yaitu Peraturan Desa. ${ }^{3}$ Sehubungan dengan telah di uraikan, maka penulis tertarik melakukan penelitian dengan judul tesis, "Tinjauan Hukum Kewenangan Pengujian Peraturan Desa".

\section{METODE PENELITIAN}

Penelitian ini akan disusun dengan menggunakan tipe penelitian yuridis normatif, yaitu penelitian yang difokuskan untuk mengkaji penerapan kaidah-kaidah atau norma-norma dalam hukum. ${ }^{4}$ Yuridis Normatif, yaitu pendekatan yang menggunakan konsepsi legis positivis. Konsep ini memandang hukum identik dengan norma-norma tertulis yang dibuat dan diundangkan oleh lembaga atau pejabat yang berwenang. Konsepsi ini memandang hukum sebagai suatu sistem normatif yang bersifat mandiri, tertutup dan terlepas dari kehidupan masyarakat yang nyata. 5

\section{ANALISIS DAN PEMBAHASAN}

\section{Konsep dan Bentuk Pengujian Konstitusionalitas Peraturan Perundang-undangan.}

Dalam praktik, dikenal adanya tiga macam norma hukum yang dapat diuji atau yang biasa disebut sebagai norm control mechanism. Ketiganya sama-sama merupakan bentuk norma hukum sebagai hasil dari proses pengambilan keputusan hukum, yaitu:

1. keputusan normatif yang berisi dan bersifat pengaturan (regeling).

2. keputusan normatif yang berisi dan bersifat penetapan administratif (beschikking).

3. keputusan normatif yang berisi dan bersifat penghakiman (jugdgement) yang biasa disebut vonis. ${ }^{6}$

Ketiga bentuk norma hukum tersebut di atas, ada yang merupakan individual and concrete norm, dan ada pula yang merupakan general and abstract norm. Vonis dan beschikking selalu bersifat individual and concrete norm, sedangkan regeling selalu bersifat general and abstract norm. ${ }^{7}$

3 H. M. Laica Marzuki, Berjalan-jalan di Ranah Hukum, Jakarta: Sekretariat Jenderal dan Kepaniteraan Mahkamah Konstitusi Republik Indonesia, 2006, hlm. 38

4 Johnny Ibrahim, Teori dan Metodologi Penelitian Hukum Normatif, Malang: Bayumedia Publishing, 2006, hlm. 295

5 Ronny Hanitijo Soemitro, Metodologi Penelitian Hukum dan Jurimetri, Jakarta: Ghalia Indonesia, 1988, hlm. 13-14

6 Jimly Asshiddiqie, Hukum Acara Pengujian Undang-Undang, Cetakan Kedua, Jakarta: Sekretariat Jenderal dan Kepaniteraan Mahkamah Konstitusi RI, 2006, hlm. 1

7 Jimly Asshiddiqie, Perihal Undang-Undang, Jakarta: Konstitusi Press, 2006, hlm. 6 
Terhadap berbagai bentuk norma hukum tersebut di atas, dapat dilakukan kontrol atau pengawasan melalui apa yang biasa disebut sebagai mekanisme kontrol norma hukum (legal norm control mechanism). Kontrol terhadap norma hukum itu dapat dilakukan melalui pengawasan atau pengendalian politik, pengendalian administratif, atau melalui kontrol hukum (judicial). ${ }^{8}$

Bentuk pengujian konstitusionalitas peraturan perundang-undangan dijelaskan oleh Bagir Manan bahwa untuk menjaga agar kaidah-kaidah konstitusi lainnya tidak dilanggar, perlu ada badan serta tata cara mengawasinya. Dalam literatur yang ada terdapat tiga kategori besar pengujian peraturan perundang-undangan dan perbuatan administrasi negara, yaitu:

1. Pengujian oleh badan peradilan (judicial review).

2. Pengujian oleh badan yang sifatnya politik (political review).

3. Pengujian oleh pejabat atau badan eksekutif negara (executive review). ${ }^{9}$

Jimly Asshiddiqie di dalam bukunya berjudul Model-Model Pengujian Konstitusional Di Berbagai Negara banyak menjelaskan tentang constitutional review, judicial review, political review, dan executive review. Berikut ulasannya:

\section{Model Constitutional Review}

Sejarah institusi yang berperan melakukan kegiatan constitutional review di dunia berkembang pesat melalui tahap-tahap pengalaman yang beragam di setiap negara. Ada yang melembagakan fungsi pengujian konstitusional itu dalam lembaga yang tersendiri bernama Mahkamah Konstitusi. Ada pula yang mengaitkan fungsi pengujian itu kepada lembaga yang sudah ada, yaitu Mahkamah Agung. Ada pula yang memberikan tugas untuk menjalankan fungsi pengujian itu kepada badan-badan khusus dalam kerangka lembaga-lembaga lain seperti badan-badan pengadilan yang sudah ada, dan ada pula yang tidak menerima adanya fungsi pengujian semacam itu sama sekali. Pengalaman di berbagai negara di dunia memperlihatkan bahwa tradisi yang mereka ikuti tidak sama dari satu negara ke negara yang lain. ${ }^{10}$

\section{Model Judicial Review}

Dalam konsep pengujian Undang-undang, khususnya berkaitan dengan pengujian oleh kekuasaan kehakiman, perlu dibedakan pula antara istilah judicial review dan judicial preview.

8 Ni'matul Huda, Hukum Pemerintahan Daerah, Cetakan Ketiga, Bandung: Nusa Media, 2012, hlm. 113

9 Ni'matul Huda, Negara Hukum, Demokrasi Dan Judicial Review, Yogyakarta: UII Press, 2005, hlm. 73

10 Jimly Asshiddiqie, Model-Model Pengujian Konstitusional Di Berbagai Negara, Cetakan Pertama, Jakarta: Sinar Grafika, 2010, hlm. 1 
Review berarti memandang, menilai, atau menguji kembali, yang berasal dari kata re dan view. Sedangkan pre dan view atau preview adalah kegiatan memandangi sesuatu lebih dulu dari sempurnanya keadaan objek yang dipandang itu. ${ }^{11}$

Dalam rangka judicial review ini, hakim berhak melarang dan membatalkan tindakantindakan pemerintah yang: ${ }^{12}$

a. Dilakukan sewenang-wenang (arbitrary), semau-maunya dan berganti-ganti (capricious), penyalahgunaan wewenang diskresioner (abuse of discretion) dan lainlain tindakan yang tidak sesuai dengan hukum.

b. Bertentangan dengan hak-hak konstitusional, bertentangan dengan wewenang/kekuasaan, privilege atau immunitas.

c. Melampaui batas wewenang yang telah ditentukan oleh undang-undang atau tidak didasarkan pada suatu hak apa pun.

d. Dilakukan tanpa memperhatikan atau menuruti prosedur yang telah ditentukan oleh hakim.

e. Tidak didukung oleh kebenaran di dalam fakta-fakta persoalan yang bersangkutan yang merupakan suatu "substansial evidence" dalam tindakan pemerintah tersebut.

\section{Pengujian Peraturan Desa Dalam Sistem Hukum Di Indonesia}

Peraturan desa adalah perundang-undangan yang ditetapkan oleh kepala desa setelah dibahas dan disepakati bersama badan permusyawaratan desa. ${ }^{13}$ hal ini sebagaimana ditentukan dalam Pasal 5 Permendagri 111 Tahun 2014 tentang Pedoman Pembentukan dan Mekanisme Penyusunan Peraturan Desa:

1. Perencanaan penyusunan rancangan Peraturan Desa ditetapkan oleh Kepala Desa dan BPD dalam rencana kerja Pemerintah Desa.

2. Lembaga kemasyarakatan, lembaga adat dan lembaga desa lainnya di desa dapat memberikan masukan kepada Pemerintah Desa dan atau BPD untuk rencana penyusunan rancangan Peraturan Desa.

Frase peraturan desa adalah peraturan perundang-undangan menandakan bahwa peraturan desa sebagai suatu norma hukum yang menjadi bagian dalam sistem peraturan perundang-undangan di Indonesia. Suatu sistem tentunya, terdiri dari beberapa elemen seperti

11 Jimly Asshiddiqie, Hukum Acara, Op.Cit, hlm. 4.

12 Ni'matul Huda, Hukum Pemerintahan, Op.Cit, hlm. 119-120.

13 Lihat Pasal 1 nomor 7 Undang-Undang Republik Indonesia Nomor 6 Tahun 2014 Tentang Desa. 
norma hukum yang tersusun secara hierarkis. Maka, peraturan desa dalam hal ini, berada pada salah satu jenjang norma hukum tersebut.

Peraturan desa atau peraturan yang setingkat didefinisikan sebagai peraturan perundang-undangan yang dibentuk oleh badan perwakilan desa atau nama lainnya bersama dengan kepala desa atau nama lainnya. ${ }^{14}$ Secara hierarkis, peraturan desa menjadi bagian dalam peraturan daerah yang tersusun secara berjenjang, yaitu peraturan daerah di tingkat provinsi, peraturan daerah di tingkat kabupaten/kota, dan peraturan desa. ${ }^{15}$

Masuknya peraturan desa dalam hierarki, menandakan diakuinya keberadaannya dan memiliki kekuatan hukum yang mengikat sesuai dengan susunan hierarki peraturan perundang-undangan yang berlaku. ${ }^{16}$ Materi muatan peraturan desa adalah seluruh materi dalam rangka penyelenggaraan urusan desa atau yang setingkat serta penjabaran lebih lanjut peraturan perundang-undangan yang lebih tinggi. ${ }^{17}$

Undang-Undang Republik Indonesia Nomor 12 Tahun 2011 Tentang Pembentukan Peraturan Perundang-undangan tidak mencantumkan peraturan desa dalam hierarki peraturan perundang-undangan. Terlihat sebagaimana Pasal 7 ayat (1) tentang jenis dan hierarki peraturan perundang-undangan terdiri atas: 18

1) Undang-Undang Dasar Negara Republik Indonesia Tahun 1945;

2) Ketetapan Majelis Permusyawaratan Rakyat;

3) Undang-Undang/Peraturan Pemerintah Pengganti Undang-Undang;

4) Peraturan Pemerintah;

5) Peraturan Presiden;

6) Peraturan Daerah Provinsi; dan

7) Peraturan Daerah Kabupaten/Kota.

Berdasarkan penjelasan di atas, penghapusan peraturan Desa dalam hierarki peraturan perundang-undangan di Indonesia tidak terlepas dari pengaturan mengenai kedudukan

14 Lihat Pasal 1 nomor 8 Undang-Undang Republik Indonesia Nomor 10 Tahun 2004 Tentang Pembentukan Peraturan Perundang-undangan.

15 Lihat Pasal 7 ayat (2) huruf c Undang-Undang Republik Indonesia Nomor 10 Tahun 2004 Tentang Pembentukan Peraturan Perundang-undangan.

16 Lihat Pasal 7 ayat (4) dan (5) huruf c Undang-Undang Republik Indonesia Nomor 10 Tahun 2004 Tentang Pembentukan Peraturan Perundang-undangan.

17 Lihat Pasal 13 Undang-Undang Republik Indonesia Nomor 10 Tahun 2004 Tentang Pembentukan Peraturan Perundang-undangan.

18 Lihat Pasal 7 ayat(1) Undang-Undang Republik Indonesia Nomor 12 Tahun 2011 Tentang Pembentukan Peraturan Perundang-undangan. 
pemerintahan Desa yang tereduksi dalam Undang-Undang Republik Indonesia Nomor 32 Tahun 2004 Tentang Pemerintahan Daerah.

Menurut Jimly Asshiddiqie, peraturan desa tidak perlu dimasukkan ke dalam kategori peraturan perundang-undangan negara. Peraturan desa tidak dapat dipersamakan dengan pengertian peraturan daerah, mengingat pemerintahan desa berbeda dengan pemerintahan daerah. Pemerintahan desa berangkat dari konsep kehidupan masyarakat berbentuk komunitas yang dapat mengurus dirinya sendiri. Masyarakat desa merupakan self-governing communities (zelfbestuur gemeinschap) yang menjadi unit-unit kegiatan masyarakat di luar pengertian formal daya jangkau organisasi negara. ${ }^{19}$

Berdasarkan penjelasan di atas, pendapat Jimly Asshiddiqie lebih mengarahkan desa pada format aslinya yang menjalankan pemerintahan dengan otonomi asli. Pelaksanaan pemerintahan desa berdasarkan pada hukum adat yang menyesuaikan kesatuan masyarakat hukum adat masing-masing. Sifat hukum adat sendiri berbentuk hukum yang tidak tertulis dalam artian bahwa, hukum adat berbeda dengan peraturan perundang-undangan yang bersifat formal. Maka, dengan pemahaman tersebut lebih tepat jika peraturan desa tidak masuk dalam hierarki peraturan perundang-undangan dikaitkan dengan peraturan desa bahwa pemerintahan desa membuka peluang bagi berlakunya hukum adat yang telah hidup. Terlebih, dalam Pasal 104 Undang-Undang Republik Indonesia Nomor 22 Tahun 1999 Tentang Pemerintahan Daerah disebutkan bahwa parlemen desa berfungsi mengayomi adat istiadat. Pada implementasinya bisa saja penuangan adat istiadat dalam peraturan desa sehingga hukum adat muncul menjadi hukum di tingkat desa. ${ }^{20}$

Lebih lanjut, Mahfud MD menjelaskan, bahwa peradilan adalah hal yang tidak masuk dalam kewenangan otonom. Persoalan muncul jika nantinya peraturan secara hukum adat masuk ke pengadilan yang kemudian akan diputus oleh majelis hakim. Sudah menjadi konsekuensi, ketika Indonesia menerapkan sistem hukum yang cenderung menganut paham legisme yang berpandangan bahwa hukum adalah undang-undang yang dibentuk oleh lembaga legislatif, maka, hakim akan mengalami kesulitan untuk memutus perkara dari peraturan desa yang berdasarkan adat masing-masing yang berbeda. ${ }^{21}$

Berdasarkan penjelasan di atas, pendapat yang disampaikan Mahfud MD lebih cenderung mengarahkan bahwa peraturan desa memiliki problematika dalam tataran praktik.

19 Jimly Asshiddiqie, Pengantar Ilmu Hukum Tata Negara, Jilid I, Konstitusi Press, Jakarta, 2006, hlm. 221

20 Ni'matul Huda, Hukum, Op. Cit, hlm. 263.

21 Ibid, hlm. 264 
Jika hanya didasarkan pada hukum adat yang bersifat tidak tertulis, dalam artian bahwa tidak secara formal sebagaimana peraturan perundang-undangan. Indonesia yang secara sistem hukum cenderung menguatkan hukum tertulis yang formal, akan memberikan kesulitan kepada hakim untuk memutus perkara yang sumber materiilnya tidak ada dalam peraturan perundang-undangan formal, terlebih jika kedua peraturan berbenturan. Oleh karena itu, peraturan desa setidaknya ditata baik secara jenis baik itu yang formal maupun berdasarkan adat, berikut dengan hierarki peraturan desa dalam sistem peraturan perundang-undangan agar menjadi jelas kedudukan peraturan desa jika terjadi benturan dengan peraturan yang lebih tinggi secara hierarkis.

\section{Pengawasan Peraturan Desa Setelah Berlakukannya Undang-Undang Republik Indonesia Nomor 6 Tahun 2014 Tentang Desa.}

Desa dengan pemerintahan yang memiliki hak otonomi diberikan melalui ketentuan yang diatur dalam Undang-Undang Republik Indonesia Nomor 6 Tahun 2014 Tentang Desa. Pemerintahan Desa yang otonom diberikan kewenangan untuk membentuk suatu produk hukum yang disebut peraturan Desa. Pemberian kewenangan tersebut juga sekaligus membawa konsekuensi pada pengawasan terhadap peraturan Desa.

Penegasan tentang batasan kewenangan pembentukan peraturan Desa sebagaimana dimaksud bahwa suatu peraturan Desa dilarang bertentangan dengan kepentingan umum atau ketentuan peraturan perundang-undangan yang lebih tinggi. ${ }^{22}$ Selanjutnya, sebagaimana disebutkan dalam Pasal 115 huruf e, bahwa pemerintah kabupaten atau kota berwenang mengevaluasi dan melakukan pengawasan terhadap peraturan Desa. ${ }^{23}$

Peraturan Desa yang telah diundangkan, kemudian disampaikan kepada Bupati/Walikota sebagai bahan pembinaan dan pengawasan paling lambat 7 (tujuh) hari setelah diundangkan. ${ }^{24}$ Tindakan pengawasan yang dilakukan oleh pemerintah kabupaten/kota diwujudkan dalam bentuk pembatalan oleh Bupati atau Walikota ketika suatu peraturan Desa dan peraturan kepala Desa yang bertentangan dengan kepentingan umum atau ketentuan peraturan perundang-undangan yang lebih tinggi. ${ }^{25}$

22 Lihat Pasal 69 ayat (2) Undang-Undang Republik Indonesia Nomor 6 Tahun 2014 Tentang Desa.

23 Lihat Pasal 115 huruf e Undang-Undang Republik Indonesia Nomor 6 Tahun 2014 Tentang Desa.

24 Lihat Pasal 84 ayat (4) Peraturan Pemerintah Nomor 43 Tahun 2014 Peraturan Pelaksanaan Undang-Undang Republik Indonesia Nomor 6 Tahun 2014 Tentang Desa.

25 Lihat Pasal 87 Peraturan Pemerintah Nomor 43 Tahun 2014 Peraturan Pelaksanaan Undang-Undang Republik Indonesia Nomor 6 Tahun 2014 Tentang Desa. 
Proses menuju pembatalan dilakukan dengan tahapan bahwa, peraturan Desa yang telah diundangkan disampaikan oleh kepala Desa kepada Bupati atau Walikota paling lambat 7 (tujuh) hari sejak diundangkan untuk diklarifikasi. Bupati atau Walikota melakukan klarifikasi peraturan Desa dengan membentuk tim klarifikasi paling lambat 30 hari sejak diterima. ${ }^{26}$ Hasil klarifikasi dibagi dalam dua hasil, yakni pertama, hasil klarifikasi yang sudah sesuai dengan kepentingan umum, atau ketentuan Peraturan perundang-undangan yang lebih tinggi; kedua, hasil klarifikasi yang bertentangan dengan kepentingan umum atau ketentuan Peraturan perundang-undangan yang lebih tinggi. Ketika hasil klarifikasi bertentangan dengan kepentingan umum, atau ketentuan peraturan perundang-undangan yang lebih tinggi Bupati atau Walikota membatalkan peraturan Desa tersebut dengan keputusan. ${ }^{27}$

Terkhusus, mengenai rancangan peraturan Desa tentang Anggaran Pendapatan dan Belanja Desa (APBDesa), pungutan, tata ruang, dan organisasi pemerintah desa harus mendapatkan evaluasi dari Bupati atau Walikota sebelum ditetapkan menjadi peraturan Desa. ${ }^{28}$ Peraturan Desa tersebut disampaikan kepada Bupati atau Walikota melalui camat atau sebutan lain paling lambat 3 hari sejak disepakati untuk dievaluasi. ${ }^{29}$ Bupati atau Walikota dapat membentuk tim evaluasi rancangan peraturan Desa. ${ }^{30}$

Hasil evaluasi diserahkan oleh Bupati atau Walikota paling lama 20 hari kerja terhitung sejak diterimanya rancangan peraturan tersebut oleh Bupati atau Walikota. Dalam hal Bupati atau Walikota telah memberikan hasil evaluasi, kepala Desa wajib memperbaikinya. Kepala Desa diberi waktu paling lama 20 hari sejak diterimanya hasil evaluasi untuk melakukan koreksi. Apabila Bupati atau Walikota tidak memberikan hasil evaluasi dalam batas waktu telah ditentukan, maka peraturan Desa tersebut berlaku dengan sendirinya. ${ }^{31}$ Pengawasan produk hukum pemerintahan Desa yang diatur melalui peraturan perundang-undangan setelah pemberlakuan Undang-Undang Republik Indonesia Nomor 6 Tahun 2014 Tentang Desa hanya memperlihatkan pengawasan melalui lembaga administratif (administrative/executive review) dan pengawasan melalui lembaga politik (political review). Proses pengawasan melalui lembaga peradilan (judicial review) tidak diatur dalam ketentuan tersebut.

26 Lihat Pasal 19 Peraturan Menteri Dalam Negeri Nomor 111 Tahun 2014 Tentang Pedoman Peraturan di Desa.

27 Lihat Pasal 20 Peraturan Menteri Dalam Negeri Nomor 111 Tahun 2014 Tentang Pedoman Peraturan di Desa.

28 Lihat Pasal 69 ayat (4) Undang-Undang Republik Indonesia Nomor 6 Tahun 2014 Tentang Desa.

29 Lihat Pasal 14 ayat (1) Peraturan Menteri Dalam Negeri Nomor 111 Tahun 2014 Tentang Pedoman Peraturan di Desa.

30 Lihat Pasal 18 ayat (1) Peraturan Menteri Dalam Negeri Nomor 111 Tahun 2014 Tentang Pedoman Peraturan di Desa.

31 Lihat Pasal 69 ayat (4) Undang-Undang Republik Indonesia Nomor 6 Tahun 2014 Tentang Desa. 
Pengawasan melalui lembaga administratif (administrative/executive review) dilakukan oleh pemerintahan kabupaten/kota yang secara hierarki lebih tinggi dari pemerintahan Desa. Pengawasan yang dilakukan terhadap peraturan Desa tidak menggunakan pola yang sama. Peraturan desa tentang APBDes, pungutan, tata ruang, dan organisasi pemerintah Desa dilakukan dengan metode pengawasan preventif terhadap peraturan Desa yakni, sebelum peraturan desa tersebut diundangkan dan secara pengawasan secara represif apabila kepala desa dan badan perwakilan Desa tidak melakukan perbaikan atas evaluasi yang dilakukan oleh Bupati/Walikota.

Peraturan Desa secara umum berkaitan dengan pelaksaan kewenangan pemerintahan Desa diawasi secara represif yang dilakukan terhadap peraturan Desa setelah diundangkan. Dimulai dari tahapan mekanisme klarifikasi yang berujung pada pembatalan peraturan desa apabila bertentangan dengan kepentingan umum dan/atau bertentangan dengan peraturan yang lebih tinggi melalui keputusan Bupati/Walikota.

Ukuran bagi bertentangan kepentingan umum sebagaimana dimaksud adalah 1) terganggunya kerukunan antar warga masyarakat; 2) terganggunya akses terhadap pelayanan publik; 3) terganggunya ketenteraman dan ketertiban umum; 4) terganggunya kegiatan ekonomi untuk meningkatkan kesejahteraan masyarakat Desa; kelima, diskriminasi terhadap suku, agama dan kepercayaan, ras, antar golongan, serta gender. ${ }^{32}$ Sedangkan ukuran bagi bertentangan dengan peraturan yang lebih tinggi diukur melalui hierarki peraturan perundangundangan.

\section{Pengawasan Peraturan Desa Dalam Peraturan Perundang-undangan.}

Pengawasan terhadap peraturan Desa dilaksanakan dengan dua aspek pembahasan, yaitu:

1. Dari sisi penyelenggaraan pemerintahan negara, dimana pemerintahan yang lebih tinggi berwenang untuk melakukan pengawasan terhadap proses penyelenggaraan pemerintahan Desa dalam menjalankan kewenangannya berdasarkan hak otonomi yang salah satunya membentuk suatu peraturan;

2. Dari sisi peraturan desa sebagai norma yang harus sesuai dengan prinsip dalam pembentukan suatu peraturan perundang-undangan.

Hubungan antara pemerintahan pusat, pemerintahan daerah, dan pemerintahan Desa dalam konteks negara kesatuan membutuhkan pengawasan yang tersusun menyesuaikan

\footnotetext{
32 Lihat Penjelasan Umum Nomor 7 Undang-Undang Republik Indonesia Nomor 6 Tahun 2014 Tentang Desa.
} 
hierarki struktural pemerintahan negara. Pengawasan akan menjadi pengikat kesatuan, sehingga kebebasan otonomi tidak bergerak menuju kedaulatan hingga mengancam kesatuan. Pengawasan yang dilakukan tidak dalam rangka membelenggu kebebasan itu sendiri, oleh karenanya pelaksanaan pengawasan perlu dibatasi berkaitan dengan bentuk, tata cara, dan lembaga yang berwenang melakukan pengawasan sesuai dengan ketentuan peraturan perundang-undangan. ${ }^{33}$

Ketika mengaitkan antara pengawasan dalam bentuk pengujian peraturan perundangundangan, terdapat beberapa hal yang memperlihatkan urgensi pengujian terhadap suatu peraturan dilakukan, seperti: ${ }^{34}$

1. Salah satu unsur negara hukum adalah setiap tindakan pemerintah atau pemerintahan harus berdasarkan hukum dan peraturan perundang-undangan yang berlaku. Negara diselenggarakan tidak atas kemauan semata oleh penguasa, tetapi negara diperintah berdasarkan hukum yang sudah dibuat dan disediakan sebelumnya serta penguasa tunduk pada hukum tersebut.

2. Jika dikaitkan dengan tipe negara kesejahteraan modern yang dianut oleh UUD 1945, dimana pemerintah diberi kewenangan yang sangat luas untuk ikut serta aktif campur tangan dalam segala bidang sosial budaya dan ekonomi. Dengan kewenangan pemerintah yang begitu luas tersebut, jika tidak dipagari dengan aturan-aturan hukum yang baik dan adil, serta pengawasan penggunaan kewenangan yang ketat dapat menimbulkan kesewenang-wenangan dari pemerintah.

3. Secara umum tujuan pembentukan perundang-undangan adalah mengatur dan menata kehidupan dalam suatu negara supaya masyarakat yang diatur oleh hukum itu memperoleh kepastian, kemanfaatan dan keadilan di dalam kehidupan bernegara dan bermasyarakat. Oleh karena itu, salah satu tiang utama dalam penyelenggaraan pemerintahan suatu negara hukum adalah pembentukan peraturan perundang-undangan yang baik, harmonis, dan mudah diterapkan dalam masyarakat.

33 Sir Wiliam O. Hart-J.F Garner, Introduction To The Law of The Local Government and Adminitration, Butterworths, London, 1973, hlm. 297. Dalam Bagir Manan, Hubungan Antara Pusat Daerah Menurut UUD 1945, Pustaka Sinar Harapan, Jakarta, 1994, hlm. 181.

34 Jalaluddin, "Hakikat dan Fungsi Peraturan Perundang-undangan Sebagai Batu Uji Kritis Terhadap Gagasan Pembentukan Perda Yang Baik", Aktualita, Vol 6, No 3 (2011). hlm. 1-2. 
Berdasarkan ketiga alasan tersebut, menjadikan suatu peraturan Desa penting untuk dibentuk dengan dilakukannya pengawasan yang baik terhadap peraturan Desa. Pengujian peraturan perundang-undangan sebagai bentuk pengawasan terhadap norma hukum dapat dilakukan dengan baik, ketika tiga mekanisme pengujian, yakni administrative/executive review, political review, dan judicial review diberlakukan terhadap suatu peraturan perundangundangan. Melalui ketiga mekanisme tersebut kemudian dilakukan pengujian secara materi muatan (materiele toetsingrecht) dan prosedur pembentukan peraturan perundang-undangan (formele toetsingrecht).

Pilihan lain dalam proses pengujian peraturan Desa adalah keputusan pembatalan yang dikeluarkan oleh Bupati atau Walikota diajukan ke peradilan tata usaha negara apabila pemerintahan Desa merasa keberatan dengan keputusan tersebut. Hal ini sejalan dengan ketentuan Undang-Undang Republik Indonesia Nomor 30 Tahun 2014 Tentang Administrasi Pemerintahan Pasal 1 angka 7 yang menjelaskan bahwa: Keputusan Administrasi Pemerintahan yang juga disebut Keputusan Tata Usaha Negara atau Keputusan Administrasi Negara yang selanjutnya disebut Keputusan adalah ketetapan tertulis yang dikeluarkan oleh Badan atau Pejabat Pemerintahan dalam penyelenggaraan pemerintahan. ${ }^{35}$ Selanjutnya, diatur bahwa keputusan dapat dibatalkan oleh: 1) pejabat pemerintahan yang menetapkan keputusan; 2) atasan pejabat yang menetapkan keputusan; 3) atas putusan pengadilan. ${ }^{36}$ Pengadilan yang dimaksud adalah pengadilan tata usaha negara. ${ }^{37}$

Ketentuan lain yang juga dapat melibatkan lembaga peradilan dalam proses pengujian peraturan Desa adalah ketentuan dalam Undang-Undang Republik Indonesia Nomor 12 Tahun 2011 Tentang Pembentukan Perundang-undangan. Sebagaimana ketentuan Pasal 9 ayat (2) menyebutkan bahwa peraturan perundang-undangan di bawah undang-undang diduga bertentangan dengan undang-undang, pengujiannya dilakukan oleh Mahkamah Agung. ${ }^{38}$ Peraturan Desa yang kedudukannya diakui dan memiliki kekuatan hukum yang mengikat melalui ketentuan Pasal 8 ayat (2), karena kewenangan yang dimiliki oleh kepala Desa dan Badan Permusyawaratan Desa diperintahkan oleh Undang-Undang Republik Indonesia Nomor

35 Lihat Ketentuan Umum Pasal 1 angka 7 Undang-Undang Republik Indonesia Nomor 30 Tahun 2014 Tentang Administrasi Pemerintahan.

36 Lihat Pasal 66 ayat (3) Undang-Undang Republik Indonesia Nomor 30 Tahun 2014 Tentang Administrasi Pemerintahan.

37 Lihat Ketentuan Umum Pasal 1 angka 18 Undang-Undang Republik Indonesia Nomor 30 Tahun 2014 Tentang Administrasi Pemerintahan.

38 Lihat Pasal 9 ayat(2) Undang-Undang Republik Indonesia Nomor 12 Tahun 2011 Tentang Pembentukan Peraturan Perundang-undangan. 
6 Tahun 2014 Tentang Desa. Oleh karena itu, dengan pemahaman bahwa peraturan Desa merupakan peraturan perundang-undangan yang berada di bawah undang-undang dapat diujikan ke Mahkamah Agung.

Jika dikaitkan dengan konsep judicial review yang diterapkan di Indonesia yang menganut paham civil law, pengujian peraturan perundang-undangan di bawah undangundang dilakukan oleh satu atap lembaga peradilan, yaitu Mahkamah Agung. Mahkamah Agung membawahi lingkup peradilan umum, peradilan agama, peradilan militer, peradilan tata usaha negara. ${ }^{39}$ Alternatif pilihan yang kemudian muncul adalah Mahkamah Agung mendelegasikan kewenangan dalam pengujian peraturan perundang-undangan terkhusus untuk peraturan Desa yang diduga bertentangan dengan peraturan yang lebih tinggi atau undang-undang itu sendiri kepada lembaga peradilan yang berada di bawahnya.

Berdasarkan penjelasan di atas, pilihan yang relevan adalah memberikan kewenangan kepada peradilan tata usaha negara yang mengadili perkara pengujian peraturan Desa mengatasnamakan Mahkamah Agung.

\section{KESIMPULAN}

Pengujian pembatalan peraturan Desa oleh Bupati atau Walikota berdasarkan Pasal 87 Peraturan pemerintah Nomor 43 Tahun 2014 Tentang Pelaksanaan Undang-Undang Republik Indonesia Nomor 6 Tahun 2014 Tentang Desa yang kemudian diatur berdasarkan Perda Buton Utara Nomor 5 Tahun 2015 Pasal 19 dan Pasal 22 baik dalam bentuk evaluasi maupun klarifikasi dapat dilakukan pengujian. Adapun dasar pengujian yang digunakan adalah UndangUndang Republik Indonesia Nomor 4 Tahun 2004 Tentang Kekuasaan Kehakiman Pasal 11 ayat (2) huruf b yang menyatakan bahwa Mahkamah Agung mempunyai kewenangan menguji peraturan perundang-undangan di bawah Undang-Undang terhadap Undang-Undang dan ayat (3) yang menyatakan bahwa pernyataan tidak berlaku peraturan perundang-undangan sebagai hasil pengujian sebagaimana yang dimaksud pada Pasal 2 huruf b, dapat diambil baik dalam pemeriksaan tingkat kasasi maupun berdasarkan permohonan langsung kepada Mahkamah Agung. Selain itu, tata cara permohonan pengujian peraturan perundang-undangan di bawah Undang-Undang diatur berdasarkan Undang-Undang Republik Indonesia Nomor 5 Tahun 2004 tentang perubahan atas Undang-Undang Republik Indonesia Nomor 14 Tahun 1985 tentang Mahkamah Agung Pasal 31 A ayat (1) dan ayat (2) huruf a, b, c.

39 Lihat Pasal 24 ayat (2) Undang-Undang Dasar Negara Republik Indonesia Tahun 1945 


\section{Daftar Pustaka}

\section{Buku}

Asshiddiqie, Jimly, Hukum Acara Pengujian Undang-Undang, Cetakan Kedua, Jakarta: Sekretariat Jenderal dan Kepaniteraan Mahkamah Konstitusi RI, 2006.

Asshiddiqie, Jimly, Model-Model Pengujian Konstitusional Di Berbagai Negara, Cetakan Pertama, Jakarta: Sinar Grafika, 2010.

Asshiddiqie, Jimly, Pengantar Ilmu Hukum Tata Negara, Jilid I, Jakarta: Sekretariat Jendral dan Kepanitraan MK RI, 2006.

Asshiddiqie, Jimly, Pengantar Ilmu Hukum Tata Negara, Jilid I, Konstitusi Press, Jakarta, 2006 Asshiddiqie, Jimly, Perihal Undang-Undang, Jakarta: Konstitusi Press, 2006.

Huda, Ni'matul, Hukum Pemerintahan Daerah, Cetakan Ketiga, Bandung: Nusa Media, 2012.

Huda, Ni'matul, Negara Hukum, Demokrasi Dan Judicial Review, Yogyakarta: UII Press, 2005.

Ibrahim, Johnny, Teori dan Metodologi Penelitian Hukum Normatif, Malang: Bayumedia Publishing, 2006.

Manan, Bagir, Hubungan Antara Pusat Daerah Menurut UUD 1945, Pustaka Sinar Harapan, Jakarta, 1994.

Marzuki, H. M. Laica, Berjalan-jalan di Ranah Hukum, Jakarta: Sekretariat Jenderal dan Kepaniteraan Mahkamah Konstitusi Republik Indonesia, 2006.

Soemitro, Ronny Hanitijo, Metodologi Penelitian Hukum dan Jurimetri, Jakarta: Ghalia Indonesia, 1988.

\section{Jurnal dan Makalah}

Jalaluddin, "Hakikat dan Fungsi Peraturan Perundang-undangan Sebagai Batu Uji Kritis Terhadap Gagasan Pembentukan Perda Yang Baik”, Aktualita, Vol 6, No 3, 2011.

\section{Peraturan Perundang-undangan}

Undang-Undang Dasar Negara Republik Indonesia Tahun 1945.

Undang-Undang Republik Indonesia Nomor 10 Tahun 2004 Tentang Pembentukan Peraturan Perundang-undangan.

Undang-Undang Republik Indonesia Nomor 12 Tahun 2011 Tentang Pembentukan Peraturan Perundang-undangan.

Undang-Undang Republik Indonesia Nomor 6 Tahun 2014 Tentang Desa. 
Undang-Undang Republik Indonesia Nomor 30 Tahun 2014 Tentang Administrasi Pemerintahan.

Peraturan Pemerintah Nomor 43 Tahun 2014 tentang Peraturan Pelaksanaan Undang-Undang Republik Indonesia Nomor 6 Tahun 2014 Tentang Desa.

Peraturan Menteri Dalam Negeri Nomor 111 Tahun 2014 Tentang Pedoman Peraturan di Desa. 